R. Anderson: Dispossession in Baja California Sur

ORIGINAL ARTICLE [In press, Economic Anthropology]

\title{
Roads, value, and dispossession in Baja California Sur, Mexico
}

Ryan Anderson

Department of Anthropology, University of Kentucky, Lexington, KY 40506, USA

Corresponding author: Ryan Anderson; e-mail: ryananderson@uky.edu

This article utilizes theories of value and space, along with Harvey's notion of "accumulation by dispossession," to critically investigate the histories and social effects of the commodification of place on the East Cape of Baja California Sur, Mexico. The article defines value as the product of specific social relations and examines how places are created, valued, commodified, and coopted in the development process. The actual process of co-optation, however, is highly contingent on the development of infrastructure, particularly roads, which play a vital yet ambivalent role in shaping how different people not only access but also value the East Cape. Keywords: Commodification, Value, Place, Dispossession, Roads, Baja California Sur, Mexico

We abuse land because we regard it as a commodity belonging to us. When we see land as a community to which we belong, we may begin to use it with love and respect.

-Aldo Leopold, A Sand County Almanac 
Lorenzo told the story about the last land conflict. In 2009, a group of approximately 40 people descended upon the small coastal community of Cabo Pulmo. Armed with wire cutters, they were there to take possession of a small parcel of highly disputed land on Cabo Pulmo Point. Local community members, armed with machetes, shovels, and Molotov cocktails, quickly organized and confronted the invaders. The confrontation didn't last long. One vehicle was smashed. Heated words were exchanged. But the invaders finally backed down and left.

Lorenzo has lived in Cabo Pulmo for longer than 15 years. He married into one of the primary families in the community. When I asked why these land invasions were happening, he told me another quick story. He said one of the men who participated in the invasion lived in the neighboring pueblo of La Ribera. Lorenzo ran into this man when he was in La Ribera running errands. He asked the man why he took part in the land grab. "Because there's no work," the man answered. Lorenzo paused, then told me, "It all comes down to the value of the land." People are fighting, he continued, because they are seemingly "walking on money." Then Lorenzo turned to me and asked, "Who could have guessed this land would someday be worth so much?"

Indeed, who could have guessed? During the past three decades, tourism and real estate development have expanded tremendously throughout the "cape region" of Baja California Sur, Mexico. Most notably, the coastal city of Los Cabos has grown into one of Mexico's premier tourism destinations. But this success has not come without problems, which include high levels of socioeconomic inequality (see López-López et al. 2006; Wilson 2008; Gámez 2012) and a consistent pattern in which local residents have been displaced and dispossessed by rising land values and costs of living (López-López et al. 2006:372-373). Similar patterns of rapid growth and displacement have occurred in other destinations throughout Mexico, most notably Cancún 
(Hiernaux 1999; Castellanos 2010; Torres and Momsen 2005). In Baja California Sur, this pattern of development is expanding into the region known informally as the East Cape, which is located on the opposite side of the cape from Los Cabos.

For years the East Cape has remained relatively undeveloped and sparsely populated. Today, real estate and tourism development pressures are slowly changing the face of this "remote" part of the peninsula. This development push has attracted a steady stream of new residents and outside investors, and rapidly rising land values (in addition to growing costs of living) are slowly squeezing many local residents out of the region. These social transformations are the result of dramatic shifts in value, caused, in part, by the commodification of place, market integration, and real estate speculation.

\section{Background}

Of course, when Lorenzo talks about people walking on money, this is not literally the case. The land values he mentions are actually prices, which are unrealized, often speculative labels placed on pieces of land. Such values are "fictitious" in many senses—but that doesn't mean they do not have real, material effects. Clearly, as Lorenzo's story illustrates, they do. So how did things get to this point? Before we move forward, a little background is in order.

The "East Cape" is an informal name for the portion of the cape region that extends from the northern edge of San Jose del Cabo to the pueblo of Los Barriles (see Figures 1 \& 2). For this article, I focus on two small East Cape communities located alongside one another: Cabo Pulmo and Las Barracas. Both of these communities are adjacent to the Cabo Pulmo National Park, a Marine Protected Area established in 1995 (see Reyes Bonilla 1997; Aburto-Oropeza et al. 2011; Gámez 2008). 
[FIGURES $1 \& 2$ HERE]

Figure 1 Location of Baja California Sur, Mexico.

Figure 2 The East Cape of Baja California Sur.

The combined population of Cabo Pulmo and Las Barracas is fewer than 300 people (see Supplementary Note 1). According to INEGI, 58 Mexican residents resided in Cabo Pulmo in 2005, and 50 lived there in 2010 (Las Barracas is included in these numbers; see INEGI 2005, 2010). Both communities are dominated by expats (primarily from the United States and Canada). In Cabo Pulmo, there are approximately 150 expats, more than twice the number of Mexican residents. Because of seasonality, the expat populations fluctuate quite dramatically. Peak season is from about October to May, which is when most of the expats tend to be in residence. During the hot summer months, their numbers drop substantially. Most of the local Mexican residents, conversely, live there year round.

Of the two communities, Cabo Pulmo is much more closely linked with the local tourism economy and the national park. Las Barracas is primarily residential, and although many members of the community use the park and participate in park activities, they are less directly associated with the local ecotourism economy. The community of Cabo Pulmo, conversely, is directly connected with the park in multiple ways. The community includes not only residences but also dive shops, restaurants, and other small businesses that depend on ecotourism activities (see Gámez 2008). The vast majority of Mexican residents are directly or indirectly involved in tourism-related businesses (Gámez 2008).

Infrastructural development, services, and public space are extremely limited in both communities. One primary unpaved road passes through the communities and connects them. This road is known as the East Cape Road. In addition, neither community has municipal water 
or electricity. Cabo Pulmo has two small stores where residents and visitors can purchase very basic supplies. It also has a small preschool and an office for the local political representative (the subdelegado) as well as a "community learning center" located alongside the preschool. Las Barracas has no stores or official public spaces. There are no health clinics, churches, plazas, police stations, or other public services in either of these communities.

Since the 1980s, this part of Baja California has been increasingly drawn into the broader real estate and tourism market. This integration began in the late 1960s and early 1970s due to several intertwined factors. The wider social and political construction of global tourism markets, particularly in relation to "Sun, Sand, and Sea" tourism (e.g., Cameron and Gatewood 2008), began with the dramatic revolutions in transportation and communication technologies that took place in the mid-twentieth century. The creation of global transportation infrastructures helped compel a reimagining of coastal places around the world as desirable, luxurious, and valuable destinations. Combined, these factors sparked Mexico's push, starting in the late 1960s, toward a national tourism economy focused on producing coastal destinations (see Clancy 2001). Legal changes, particularly the creation of the Fideicomiso (bank trust) in 1973, opened up greater opportunities for foreign investment and development throughout Mexico and the Baja peninsula (see Cabral Bowling 1998). On the East Cape, these broader global and national changes translated to a growing influx of tourists and investors.

Today, Pulmo and Barracas exist on the precipice of larger-scale investment and development. With La Paz to the north and the mega-tourism zone of Los Cabos to the south, the region seems poised for inevitable social, geographic, and economic change. To date, the primary developments include the expat enclave known as Club Las Barracas in Las Barracas and the Cabo Pulmo Beach Resort in Cabo Pulmo. The latter is a relatively small-scale operation 
that consists of privately owned units that are rented out to visiting tourists. Overall, the region remains relatively rural in character. With the promise of impending development, however, local land values have risen steadily in recent years.

The land for the Cabo Pulmo Beach Resort (approximately 200 acres) was purchased for approximately US\$100,000 in the 1970s (interview with anonymous resident, Cabo Pulmo, 2012). Weiant (2005:164) reported that a piece of coastal property could be purchased for approximately US\$10,000 in the 1980s. It is rare to see any undeveloped beachfront lots for sale in Cabo Pulmo today, but there is one listing for a 4,200 $\mathrm{m}^{2}$ beachfront lot for US $\$ 279,000$. In Las Barracas, a $6,750 \mathrm{~m}^{2}$ lot is currently listed at US\$135,000. ${ }^{1}$ Comparable undeveloped coastal lots farther south on the East Cape list for anywhere between US\$90,000 and US\$700,000. ${ }^{2}$ These increases cannot be accounted for by inflation alone: Between 1980 and 2016, annual inflation was 3.18 percent, which means land sold for US\$10,000 in 1980 would be worth approximately US\$31,000 today. The prices of beachfront lots, therefore, have increased anywhere between US\$60,000 and US\$670,000 in 35 years. These prices are unattainable for the vast majority of local Mexican residents, not to mention many of the retired, working-class expats who first ventured to this part of Baja California.

Weiant $(2005: 164)$ cites the growth boom in Los Cabos as one of the primary factors that created demand for land on the East Cape, fueling speculation and pushing Mexican households out of the region (see Supplementary Note 2). In addition to Los Cabos, however, land speculation in and around the Cabo Pulmo-Las Barracas region reached a peak beginning in 2007 and 2008 with the announcement of two new large-scale development projects: Cabo Riviera, located in La Ribera, and Cabo Cortés, located approximately $10 \mathrm{~km}$ north of Cabo Pulmo. Cabo Cortés received far more local, national, and international attention, primarily 
because of its sheer scale (see Greenpeace 2010). Cabo Riviera, at approximately 5,000 rooms, was similar in scope but much smaller in scale.

Both projects had a tremendous impact on the local real estate market. Land prices spiked, as did speculation. People started hiring armed private security guards to protect their property from squatters and land grabbers. Properties in Cabo Pulmo and Las Barracas were encircled with barbed-wire fences. Property owners erected massive "Keep Out" signs that were meant to dissuade intruders and stake a claim of ownership. Neighbors fought. Cars were burned. All of this was taking place when I started my fieldwork in 2009. The rising land values played a fundamental role in bringing about wider conflicts over land, development, and place. It was, in many senses, a battle over the very meaning of value.

\section{Value and dispossession}

In this article, I focus on the production—and eventual co-optation —of place as a primary element in the struggle over value. The actual process of co-optation, in this case, is highly contingent on the development of infrastructure - particularly roads—which critically shape how different people not only access but also value the East Cape. These roads play a complex, double-sided role in struggles over value — bad roads can work to protect and uphold certain place-based values, whereas new paved roads serve as symbolic harbingers of rapid change and dispossession.

Value is not a thing. It is, rather, an effect of particular social relations. Marx's discussions about value begin with distinctions between use-value, exchange-value, and value. The distinctions are crucial. In brief, use-value refers to what Marx calls "the usefulness of a thing" (1990:126). Use-value is the pleasure, benefit, or utility that a person gets from using and 
consuming things, whether this means literally eating food or deriving a livelihood from a place. Exchange-value is the proportion at which various use-values exchange with one another in market exchanges. Exchange-value is a relationship, one that "changes constantly with time and place" (Marx 1990:126). Marx points out that exchange-values appear to be natural, intrinsic properties of commodities themselves, but this is merely a mystification-we mistake exchangevalues (i.e., prices) for value itself. Value, for Marx, is the amount of "socially necessary labor time" (1990:129) it takes to produce a commodity or good.

Here it is important not to miss the larger point of Marx's project. His motivation was not to provide an iron-clad theory of value that worked in all times and places. Instead, Marx uses value theory as a tool to cut through the abstractions of money and markets to highlight the exploitative social relations that underpin capitalist modes of production. His goal, in works such as Capital, was to use his theory of value to point out that capitalism was a system in which human beings were simply means to the ultimate end of producing wealth, rather than the reverse (see Graeber 2013:223; Hart 2011:5).

Marx was not, Elson argues, primarily interested in explaining prices via labor "but rather of seeking an understanding of why labour takes the form that it does, and what the consequences are" (1979:123). As Graeber explains, the system of exchange-value facilitates exploitation, masks the fact that value comes from labor, and "operates on an even more insidious level to encourage us to believe that only certain forms of labor produce value in the first place" (2013:222). In other words, one lesson we can take away from Marx is that other forms of labor - and other modes of human organization - do in fact produce value. There are other possibilities. 
Like the exchange-values Marx examines, land values on the East Cape appear to be natural and intrinsic to the landscape itself. But they are not. They are, instead, the result of radically changing sociocultural relationships set within global processes of land commodification. Land values are produced within a given set of conditions. Lefebvre argues that every mode of production has "its own particular space" and that the passage from one mode to another "results from contradictions in the social relations of production which cannot fail to leave their mark on space and indeed to revolutionize it" (1991:46). The process begins with the land itself, which has to be "wrenched away" from traditional forms of property arrangement, and then extends to space, culminating in a predicament in which "the entirety of space must be endowed with exchange value" (1991:336-337).

The result of this transformation is the production of homogenous "cells" or "volumes of space" that enter the market of supply and demand and prices (Lefebvre 1991:337). These "exchangeable places" form the basis of real estate. But the connections between price, on one hand, and value, on the other, become more and more tenuous (Lefebvre 1991:337). As Lefebvre explains, "this relationship, like others, is disturbed and complicated by a variety of factors, notably by speculation" (1991:337). Lefebvre sees this process as class struggle "inscribed in space," in which specific, absolute places are being transformed into the abstract spaces of global markets (see Smith 1990:113).

A focus on labor helps demystify this process. As Mitchell once put it, to understand the meaning of a landscape — or place, I would add—we must pay close attention to "the relations of labor that were indispensable to its making" (1996:8). Although rising land values on the East Cape appear to be natural functions of the global market economy, they are, instead, largely based on the co-optation of previous forms of value that have been produced all throughout the 
region. Speculative values on the East Cape are, in other words, built on the place-making efforts (i.e., labor) of residents. This sort of value production, however, differs from the industrial conditions that shaped Marx's primary discussions about value.

Here Marx's discussion of primitive accumulation is useful. Marx (1990:874) explains that money, commodities, and the means of production and subsistence are not automatically capital. These things have to be transformed into capital. Primitive accumulation is the process through which this happens, whereby people (i.e., workers) are separated from the "social means of subsistence and production" (1990:874) and ultimately turned into wage laborers. Primitive accumulation, according to Marx, "is nothing else than the historical process of divorcing the producer from the means of production" (1990:875). This is a violent, brutal transition, "written in the annals of mankind in letters of blood and fire" (1990:875).

While Marx consigned these processes to a historical past, recent scholars (e.g., Harvey 2003, 2006; Elyachar 2005) argue that they continue in the present. According to Harvey, this process of "accumulation by dispossession" is "powerfully present within capitalism's historical geography up until now" (2003:145). Marx's discussion of primitive accumulation reveals a broad spectrum of processes, including the commodification of labor power and land (Harvey 2003:145). "Primitive accumulation," writes Harvey, "entails appropriation and co-optation of pre-existing cultural and social achievements as well as confrontation and suppression" (2003:146).

On the East Cape, value is being created—and co-opted—through ongoing patterns of dispossession. This dispossession is characterized by struggles between use-value and exchangevalues (Logan and Molotch 1987; Williams 2001). The value of a place, then, is caught between its function as a home, place of work, or livelihood (i.e., use-value) and its status as an object of 
investment, exchange, and speculation (i.e., exchange-value). Speculation, in part, helps corrode the former in favor of the latter, particularly as more and more local people are "priced out" of the market. This results in the dispossession of "possessions that bear collective identity and meaning" (Elyachar 2005:28). In effect, these processes have powerful consequences: "From an anthropological point of view," Elyachar writes, such patterns of dispossession undermine "historically constituted forms of collective identity and cosmology as well" (2005:28; see also Graeber 2001).

In the midst of the explosion of global coastal tourism, and Mexico's attempts to get a corner in that market, the coastlines of the Baja California peninsula were slowly but surely redefined as a valuable places, worthy of investment and development. This redefinition continues in the present, spurred on, in part, by ongoing processes of commodification and the slow crawl of infrastructural change. On the East Cape, value, in particular, hinges on the placemaking labors of specific communities and the various spatial and social effects of roads.

\section{Place}

For much of its history, the Baja California peninsula was seen as a barren, isolated, sometimes “worthless” place (see Anderson 2014, 2016; see also Supplementary Note 3). It was often portrayed as a marginal, unwieldy, and difficult land. But things began to change with the rise of global tourism in the mid- to late twentieth century. In a relatively short period of time, the arid coastlines of Baja California Sur were reimagined as remote, paradisiacal destinations that could draw in wealthy visitors from around the world. Suddenly, it seemed, people who were once owners of relatively worthless sandy coastal properties found themselves, as Lorenzo put it, walking on money. 
Cabo Pulmo and Las Barracas were both part of a land grant given to the Montaño family in the late nineteenth century (see Weiant 2005:156). The roots of Cabo Pulmo's present-day community can be traced back to two primary landowners: Maria Montaño Comelio and the Gonzales Canseco family. Maria Montaño and Carlos Manuel Gonzales Canseco established the first two ranching operations in the early 1900s (Weiant 2005:157). Ranching was one of the primary economic activities at the time, along with fishing and pearling (see Cariño et al. 2008:80-84). Two young men worked for María Montaño: Jesús Castro Fiol and Francisco Canedo Beltrán. Today, most of the members of the present-day community trace their roots back to one of these two men. Some families in Cabo Pulmo claim a connection that goes back five generations (Weiant 2005:156).

Some of the first expats began to arrive in the late 1960s and early 1970s. One of these early visitors, an American ski-film maker named Dick Barrymore, flew down to Cabo Pulmo and reportedly fell in love with the place. His arrival marked the beginning of a land dispute that continues to the present day. Here is the short version: Barrymore wanted to buy land, so he started asking around. He befriended Jesus Castro Fiol, who said he could sell some land. But Barrymore wanted to be sure he was buying from the right person. Ultimately, Barrymore ended up buying a large strip of land from the Gonzales Canseco family, who allegedly had legal title documents. Castro Fiol disputed the sale, saying the Gonzales Canseco family did not, in fact, have the right to sell the land. Barrymore moved ahead regardless, eventually developing the parcel into the Cabo Pulmo Beach Resort, which became the heart of the expatriate enclave (see Anderson 2014). The descendants of Jesus Castro Fiol, who form a core part of the community today, continue to dispute this sale. 
Barrymore's project marks the beginning of small-scale tourism and real estate development in Cabo Pulmo (Supplementary Note 4). According to the historical narrative from the Cabo Pulmo Beach Resort website, by the 1980s, Barrymore was well aware of the financial opportunity that lay before him. ${ }^{3}$ He created a development with a decidedly utopian vision that rebelled against (yet resembled) suburban development in the United States. Barrymore modeled the resort after a Tahitian village he had once visited. His goal was to build what one of my interviewees called a "walk-through Tahitian village" in which everything conformed to a uniform aesthetic, including codified rules resembling the "covenants, conditions, and restrictions" of many U.S. homeowners associations. He had many interested takers, particularly by the 1990s.

Today, the Cabo Pulmo Beach Resort not only includes expatriate residences but also provides rentals for visiting tourists (and associated tourism services, including a restaurant, dive shop, diving lessons, etc.) and lists parcels of land for sale. Since the 1980s, the resort has brought in many new residents and dramatically reshaped the social and geographic composition of the community. Spatially, the Cabo Pulmo Beach Resort dominates the community's social landscape.

The expatriate histories of Cabo Pulmo are only part of the story, of course. The Mexican residents of the community have been integral in the development of not only the Cabo Pulmo National Park (see Gámez 2008) but also the shift to an ecotourism-based economy. This, in turn, has altered and reshaped Cabo Pulmo as a place and destination. By the early 1980s, it became clear that years of fishing had degraded the local reef and fisheries. In conjunction with scientists and scholars from the nearby university in La Paz, local community members pushed for the creation of the national park, which was established in 1995 (Cariño et al. 2008). Despite 
the internal conflicts within the community, which are many, Cabo Pulmo was transformed from a small subsistence fishing community into an ecotourism and second-home residential destination by the early 1990 s.

Like Cabo Pulmo, the story of Las Barracas, which is located on the northern border of the national park, includes the sale of land to foreign buyers and the creation of an expatriate enclave. Bertha, a member of the Montaño family who was born in the nearby pueblo of La Ribera, has witnessed this change. While Bertha grew up mostly in La Paz, her grandparents lived in Las Barracas, and the family would often drive there to visit. But travel wasn't easy in those days. Her nuclear family was in La Paz, she explained, but all of our roots, especially because of my mother and father, were here [in Las Barracas]. So we came to this place, but not very often because it was very isolated. We would leave in the early morning. We were on the road all day. The transpeninsular highway wasn't there. [We would stay overnight in a town along the way], and then again the next day we left very early in the morning to get to Las Barracas. We would arrive that night at Las Barracas. We would do this once, sometimes twice a year to visit our grandparents. And we came to La Ribera two to three times per year. All of the roads were complicated back then, but the road to Las Barracas was even worse.

Like Cabo Pulmo, Las Barracas is located right on the coast. Bertha's grandparents had a small cattle ranch there, a small farm, and a well for water. They didn't leave the ranch much. Their primary livelihood was cattle ranching, but they also had land dedicated to agriculture. The family, Bertha explained, was “deeply rooted to this place.” They had, she added, "a deep love for the land." 
Bertha's grandparents had to sell their place in the mid-1970s because her grandfather had cancer. "When they sold the land," she recounts, "it was a painful blow for my family." It affected them deeply when they had to leave the land. They didn't return for ten years, she says. For a long time, it was a place to which they could not bear to return. "When we did return in the middle of the 1980s, ten years later, there were a lot of changes." Upon returning, she didn't recognize the hills, the place that was once her grandparents' land. There were so many dramatic changes, she said. And these changes continued. The roads between Barracas and Pulmo were much better by the mid-1990s, and this meant more tourists, new residents, and increased development.

The creation of the two expatriate communities in Cabo Pulmo and Las Barracas played a key role in the development of this region as a tourism destination and potential real estate investment. Early on, Cabo Pulmo and Las Barracas were highly valued, for some people, because they were remote, isolated, and difficult to access. This is one aspect that drew many of the first expatriate visitors - and later landowners - to this part of Baja California. They wanted to experience something unique, supposedly pristine, and exclusive. They wanted to find something far away from the overdeveloped landscapes of places like Southern California. Ironically, these early settlers actually paved the way for later waves of visitors and residents. Such a pattern betrays the wider processes through which accumulation by dispossession can work: in waves, by co-opting the achievements—and labor—of others. One thing, however, held these pressures at bay for years: terrible roads.

\section{The road}


Joseph Wood Krutch begins his book about Baja, titled The Forgotten Peninsula, with ruminations about the meaning and effects of bad roads. His first chapter starts with a story about getting stuck in the middle of the Sonoran Desert. Krutch should have been worried or stressed out, but he was instead "in that high state of elation which is sometimes (but not always) produced when one has got somewhere one has long wanted to be" (1986[1961]:4-5). His book, he tells us, is about his adventures in a remote place with "four centuries of stubborn resistance to everything called Progress" (1986[1961]:6). It is a place to which he returned "again and again to poke [his] nose into some remote areas still seldom visited, and also to taste the pleasures of others less accessible" (1986[1961]:6). Quoting some of the early missionary fathers, who referred to the peninsula as one of the most unfortunate, miserable places in the world, Krutch tells us that the once worthless landscape has taken on new meaning: "To modern travelers this place is awesome rather than merely repellant" (1986[1961]:7). He tells us about places where life isn't quite so bleak — places like La Paz and Cabo San Lucas, where outsiders can find some of the comforts of home.

But those respites, Krutch says, were exceptions in a place that was—at the time—still very isolated. His book was originally published in 1961, when the nearby town of Cabo San Lucas was just beginning its transformation from fishing village to tourism destination. Krutch refers to La Paz and Cabo San Lucas as mere "appendages" of the United States and/or mainland Mexico, not truly part of the "still wild peninsula" (1986[1961]:9-10). His story of isolation and disconnection hinges upon access:

Not until that possibly still rather distant time when a real road is built will its now marred beauty be successfully exploited and the coast turned into that string of California-style beach resorts that will be its ultimate fate. [1986(1961):10] 
It all comes down to the road. But this change will take a long time, Krutch assures us, because all previous attempts to develop the peninsula "have ended in dismal failure, for the land has always returned to its own wild self — as though it had merely shaken off the annoyance of conquistador and priest, land promoter and engineer" (1986[1961]:10). Baja, for Krutch, is a place "where time has stood still” (1986[1961]:14).

Krutch closes his first chapter by describing Baja as an "out of this world" place, one whose "charms" come from its long-standing isolation and remoteness-remoteness, I should add, in relation to certain ways of life. Decoded further: Baja was alluring, meaningful, and valuable for many Western travelers (and readers) because it represented something long lost, forgotten, or destroyed. The peninsula managed to remain in this state, in part, because there was no way to get there. No roads.

But the "real road" that Krutch lamented did eventually come. Twelve years after the publication of his book, on December 1, 1973, the transpeninsular highway was officially opened. The number of travelers who made their way down the peninsula exploded. Accessibility increased even more in the late 1970s with the creation of the international airport in Los Cabos. Still, many places remained cut off and isolated. While the western side of the cape (which includes Los Cabos) grew at an increasingly rapid rate from the 1970s onward, the eastern side saw little change. New people found their way there, but not many, mostly because of bad roads — or no roads at all. This isolation has a history.

There's a map from 1898 in the Pablo L. Martínez Archives in La Paz, BCS (Supplementary Note 5). It's a loose, hand-drawn map, showing the route that led from San Jose del Cabo to La Paz. The road heads north out of San Jose del Cabo and passes by the pueblos of Miraflores and Santiago, and then Los Barriles, on its way to the city of La Paz to the north. The 
route heads in a northerly direction, cutting across the rounded heart of the cape itself. To the east, a large chunk of the landscape remained separated from the dominant flow of social life. That swath of land is the East Cape.

During the missionary period, four missions were founded in the cape region: one in Todos Santos, another in San José del Cabo, one in Santiago, and another in La Paz. The old route, shown on the map, connected those beacons of western ideas, practices, and ways of life. Today, the paved road from San José del Cabo follows a similar inland path. Highway 1 leaves San Jose, passes through Mira Flores and Santiago, then forks at a small place called "Las Cuevas." Here you can continue north to Los Barriles, on the way to La Paz, or you can make a right turn and head toward the East Cape via the town of La Ribera.

South of La Ribera, just past Punta Arena, the paved road stops. Cabo Pulmo and Las Barracas are just a few more kilometers down the road. If the road is in good shape, it's another 15 minute drive. If the weather is bad, it will take longer. If it is really bad, you're going to have to wait. The same can be said of the rest of the unpaved East Cape coast road. Local residents often argue that this arc of unpaved road keeps many people out of the East Cape. The roads may be brutal and difficult, and they may beat the hell out of vehicles, but they also keep the place from turning into the next Cabo San Lucas; the roads are a protective barrier against unwanted change, values, and markets. They repel particular values, just as much as they reinforce and protect others.

\section{Value at $6 \mathrm{mph}$}

In 1966, two retired Americans named Pel and Peg Carter made their way down to the cape in an eight-cylinder Ford truck equipped with a cab-over camper and "all the conveniences 
except shower and toilet" (1967:168). This was their second trip. From La Paz, they drove south to Rancho Buena Vista, averaging about 7-8 mph: "The roads were just as rough, rocky, steep and full of holes as we had remembered them" (1967:174). From Rancho Buena Vista, they headed 10 miles south to the fishing resort and hotel at Punta Colorada, located north of Cabo Pulmo. They asked Bobby Van Wormer, the owner of the hotel, if he knew of a good place with a calm bay for fishing. Van Wormer pointed them to Cabo Pulmo, 12 miles south. The road was slow and rough. It took the Carters almost 2 hours to make that trip $-6 \mathrm{mph}$.

More than two decades later, Sally and Alan were introduced to the beauty and isolation of Cabo Pulmo via the very same route. They surely traveled faster than the Carters, thanks to improved road conditions, but the experience of isolation — and adventure - was similar. Sally and Alan's first trip to Cabo Pulmo was in 1995, when they were in their late forties. They had heard about the small coastal community through their employer and decided to go down for a visit. Sally tells a story about that first trip, which focuses on the unreliable car they borrowed to traverse the road to Pulmo:

Our friend said the car [he let us borrow] was not running well. He picked us up from the airport and said 'I'm quite sure you'll make it to Cabo Pulmo, but don't drive after dark, and if something should happen and the car breaks down, don't leave the car!" [she laughs]. So we're driving along — and first we stopped at the store and I was just totally overwhelmed speaking no Spanish and shopping and getting what we needed because we wanted to shop for our whole time here since we weren't coming back into town. So by the time we got that done, we [were] driving after dark. But we thought we would see how far we could go. So as it turned out we got just about half of a mile down the dirt [road] and the car went [she makes the sound of a car dying]. Everything shut off. 
Sally says they looked around and realized how dark it was. They had no idea where they were. It was so quiet, so dark. They felt like they were in the middle of nowhere. Some people stopped and offered to help. One young woman who was with her grandmother agreed to give Sally a ride to Cabo Pulmo, which is where they would meet their contact person. Alan stayed back with the car.

Sally finally arrived in Cabo Pulmo around 10 o'clock that evening. There was one light in Cabo Pulmo, and she thought to herself, "Good grief, where am I?" It took some time for their contacts in Pulmo to arrange for help. By 11 o'clock that night, Sally and Alan made it to Cabo Pulmo, with their dead vehicle in tow. At that point, they had not even seen Cabo Pulmo and had no clue what it was or what it looked like. But, as she explains, "The next morning, when we woke up and I saw where I was-I was just like 'This is it.' Somehow [I knew] I'd made it to paradise."

It was paradise because it was far away from the world of traffic and light pollution and noise. Both Sally and Alan remarked that Cabo Pulmo's "tranquility" and peacefulness were a big part of the attraction, as was the darkness - the lack of city lights. Sally told me another story about a conversation she had with a female tourist in Cabo Pulmo some years later. This woman was apparently not enjoying the remoteness of the place. She asked Sally how long she was planning on staying. Sally responded, "Well, we live here - this is where we live in the winter." But the woman said, "No, I mean here," emphasizing that last word. "You mean Cabo Pulmo?" Sally asked. The woman said, "Yes." Sally once again answered, "I live here," and the woman was completely astounded by this: "You live here in Cabo Pulmo? People live here? They actually live here? There's no electricity—how do you live here?" Sally laughed and finished up 
her story by telling me the woman was "totally blown away" and could not understand how people lived in such a situation or place by choice.

Sally, Alan, and I talked about this - how Cabo Pulmo attracts and draws in people who are looking for a certain kind of experience. They want isolation, a different way of life, a connection with a certain quality of life they feel is missing from their daily lives. Sally explained:

And that's why we have to save places like this. Or there will be no places. It's the same thing as wilderness and ... how well you make your trails-so that everybody can get there. You know? Do you build a road into everything so that it's accessible for everybody? Or do you keep some places that are hard to get to?

That difficult road is a barrier, a border (Supplementary Note 6). It simultaneously holds in and keeps out certain ideals, dreams, desires - and values. The isolation of the East Cape is a crucial part of its appeal and sociocultural value, especially for many expats. The distance—and the arduous journey it requires - helps to build up the value and mystique of this place. When I asked several expats from Cabo Pulmo how they had found the East Cape, many of them began with a narrative of their trip, which was often by car. The journey itself is a key part of the value of these places (Supplementary Note 7).

The expats of Cabo Pulmo and Las Barracas have created their own communities on the East Cape, laced with sometimes romantic, if not idyllic and utopian, hopes and expectations. Through the years, they have built places based on shared ideals, desires, and values. However, of course, Cabo Pulmo was certainly not terra incognita - there were people living there and using this place before any foreigners ever arrived. The expats exist alongside their Mexican neighbors, side by side with ambivalence, tension, and, sometimes, conflict. The communities, 
which are relatively small, mimic patterns of segregation that have developed in other parts of the peninsula (see Topmiller et al. 2011). The expats have produced places brimming with value, undoubtedly. But there are other sides to the story. One of the greatest ironies is that this valuable, off-the-grid, isolated place has, over the years, increasingly gained attention not only as a tourism destination but also as a zone ripe for investment. A slow, steady wave of dispossession follows on the heels of these changes, these value shifts.

As more people come to the East Cape, and the cost of living rises along with land values, many local Mexican residents, especially those with families, can no longer afford to stay. Pedro is one of those people. He is 32 years old and works at the family restaurant in the heart of Cabo Pulmo. He married into one of the primary families in the community about 10 years ago and came to Cabo Pulmo to live, work, and raise a family. He and his wife have two children. When he first arrived in Cabo Pulmo in 2002, he knew very little about it. Back in those days, he explained, few people throughout Mexico knew much about Cabo Pulmo. The place itself was sparsely populated, he explains: "There was nothing here. Just beautiful beaches and puro monte [pure wilderness]."

"It was all free. There were no fences in those days," he told me. He mentioned the lack of fences several times. Pedro said the majority of the fences were put up in 2005-6. The fences were a repercussion of intense social conflicts over landownership. Pedro recounted the moment when these struggles peaked: "They put up aggressive signs telling people to keep out. There were many signs, all the way along the road to Cabo Pulmo."

These conflicts over land were the result of real estate speculation and dramatically rising land values. I asked Pedro about his future in Cabo Pulmo. Does he want to stay here? He 
answered without a pause: Yes, but he can’t. "It's beautiful," he tells me, "it's safe for my kids and very peaceful . . . extremely peaceful." He continues:

But for me, as someone who is not part of the family and doesn't have any right to the land, there's no place for me and my family. I can’t build anything. I can't do anything. For obvious reasons_-my kids are growing up —I have to leave Cabo Pulmo. I don’t want to leave, but I have to.

Pedro tells me he wishes he could stay. But the land is too expensive. In addition, there are no schools or other basic resources - mostly because there's no affordable land or place to build these services. For many local Mexican families, the land and cost of living (especially in relation to employment opportunities) have become unbearable. So they leave. Pedro explains that he would stay if Cabo Pulmo had the things he needed for his family. But this just isn't the reality:

So we have to go somewhere else. And we're one of the few young married couples that have not left. But we're just about at that point. Maybe another year. And then I think my kids will go to La Paz with my wife. I'll stay here and keep working in the restaurant. This is our plan for the future. But I don't know what will happen. Pedro's story is representative of a wider pattern of accumulation by dispossession, a pattern that is ongoing yet incomplete. It is one part of the cycle of discovery, development, immigration, and out-migration that is happening to destinations like Cabo Pulmo all around the world. Butler (1980) and Cohen (1977) outlined this pattern decades ago. More adventurous travelers find new destinations, and eventually developers, realtors, investors, hoteliers, and tourists follow in their footsteps. New forms of value — and dispossession — come with them. 
Angeles grew up in Cabo Pulmo in the 1970s and 1980s. She is a direct descendant of one of the primary families in Cabo Pulmo. Angeles runs a small beachfront restaurant called La Palapa, which attracts mostly tourists and expatriate residents. Her livelihood is deeply connected with Cabo Pulmo's growing tourism economy. Tourism means money. She does not deny this. But her views about markets, change, and growth are complex, mixed, and ambivalent.

Angeles remembers the early days of Cabo Pulmo, when few people had cars and they often had to hitch rides. We talked about what it meant to live in a small, isolated community: "Well, in those days, despite the fact that people were dedicated to ranching and fishing, there was a lot of poverty," she explained. There weren't jobs, and the fishermen and ranchers often lacked markets to sell their products. Her father, she recounted, sometimes had to travel as far as Magdalena Bay for work. ${ }^{4}$ Angeles talked about the hardships of the poor roads. The isolated life that many expats fetishize over was not idyllic. It was a hard life. I ask Angeles if she would like to see a paved road wind its way into Cabo Pulmo someday. She answers:

Well, I have conflicted thoughts about this. I'd want pavement so that our cars would last a lot longer, but I think this would bring all types of people — not good people. So, it would be a lot easier for many people to come and commit crimes in the night, and our peace will be gone, our tranquility. We have already experienced this in the summers, even with the bad roads-people come and do scandalous things on our beaches. This has happened a few times - it's not very often. So, if the road was paved, it would be easier for those kinds of people to get here. To come to Cabo Pulmo for a joyride. So, on that side of things, I don't want this. . . Maybe I'd prefer no paved road at all.

Roads bring many things with them — and ambivalence is one of them. Daniel is a 55year-old fisherman who has been living in Cabo Pulmo since 1996. Like Pedro, he married into 
the community. When I asked Daniel about life in Cabo Pulmo, he said, "Everything is fine. There is no power or road ... but we're used to it." His initial answers were guarded, but later he opened up. I asked him what kind of development he would like to see in Cabo Pulmo, and his answer revealed his ambivalence toward the isolation — social and geographic — of his community. "The Mexicans here," he explained, "we are fucked [jodidos] because there is no electricity. We also need to put in a road. But that could bring more people who could rob and steal from us." I ask him if he would like to keep living in Cabo Pulmo, despite these issues. He answers:

Yes, I want to keep living here. My family is here, kids are here, it's peaceful, we all have work, but we have to protect Cabo Pulmo, it's good how it is. For me it would be good to keep things as they are, but for the future it would be good to get power, a hospital, a little school. There are more than 20 kids and they have to go all the way to La Ribera - this is what we're missing in Cabo Pulmo. That road can be dangerous. Pedro, Angeles, and Daniel all expressed conflicted, ambivalent views about the development future of Cabo Pulmo. Bertha, whose story about Las Barracas I mentioned earlier, shared her own ambivalence about life on the East Cape. Combined, these stories illustrate the conflicted histories of development and market integration in the region. These narratives highlight the possibilities and tensions that come with growing markets, yet also the dispossessing effects of commodification. Through various means, Cabo Pulmo and Las Barracas have been transformed from places to products, and each survives within this new reality. Local roads play a critical role in this process, helping to keep this place, for now, in a relatively ambiguous state. Many of the Mexican residents of Cabo Pulmo talk about their desire for health services, schools, and improved infrastructure (see Gámez and Montaño 2004:6; 
Gámez 2008). They know these are the kinds of things that may come with new development and new roads. But there is also a strong discomfort—and fear—of what else will come with those roads. People talk about the crime that will come with a new (unknown) workforce, about drugs, crowds, and pollution. They also talk about rising costs of living — and land values. The road can bring so many things— good things, unforeseen things. The lack of a paved road works, for now, as a sort of protective barrier against an unknown future.

Many people are placing bets on this uncertain future. This includes local residents, developers, and, of course, realtors. One local realtor published a short statement in which he explained why he felt the time was right to invest in the East Cape. The road played a vital role in his speculative argument:

Construction of a highway from the international airport to the East Cape region has recently attracted considerable attention. The new highway will reduce the current 50 minute drive time to only 20 minutes. In addition, the airport route will connect to another new highway system running parallel along the Sea of Cortez linking the coastal communities. Once these roads are completed, property values on the East Cape will increase substantially. This is one of the many reasons the East Cape is poised for excellent development growth and investment return. ${ }^{5}$

Paul, another local realtor with whom I spoke in 2012, thinks there will be dramatic changes when the paved road comes: big resorts, rising property values, and lots of money to be made (for some, at least). The only reason the road hasn't been paved yet, he tells me, is because of the economic downturn of 2008-9. The plans are in place, he explains, but not the money. He talked about the different waves of people who had come to the East Cape. When he first arrived in the early 1980s, he could name all the people who lived for miles around, and only three or four of 
them were "gringos." Those early waves of people were more adventurous, and subsequent waves were more and more conservative, demanding increasingly more services. Different waves, different values. "The next wave," he told me, "will be the pavement wave."

\section{Conclusion}

Today, small communities along the East Cape are increasingly recognized by the outside world — not to mention the Mexican government — as valuable places. They are places worthy of investment (see Li 2014), development, conservation — and exploitation. This change of heart was undoubtedly influenced by the East Cape's beauty, ecological diversity, and uniqueness. But this broad shift is also connected to wider social actions and changes that have taken place at various intersecting scales. The reconfiguration of the East Cape as a renewed place of value, worthy of effort and attention, has also resulted in what Elyachar refers to as a broad "conceptual shift" (2005:7). It is a shift through which supposedly desolate, "worthless" coastlines become materially and discursively transformed into abstract, commensurable spaces of solitude, beauty, and luxury—ready and waiting for capitalist investment.

This shift occurs through the work of local residents, who construct place (see Logan and Molotch 1987:44), but also of realtors, developers, government officials, planners, and others who build markets, in part, by co-opting the earlier labors of those residents. In turn, realtors, developers, and others work to reconfigure and market these places as commodities that are commensurable with other commodities around the world. This, in essence, is the process through which specific places become the abstract units of real estate. Such transformations are, as Li explains, about reformatting the social relations within which new resources are entangled and extending the "network of actors and devices connected to it" (2014:590). These 
transformations and dispossessions work in waves, and at differing scales, as the labors of earlier residents are slowly subsumed and co-opted by newer projects.

Marx's task was to expose and radically challenge a system he felt put things ahead of people. His work was meant to reverse this dynamic, to free people from the capitalistic tyranny of things (see Hart 2011:8). Marx's question was why making money has come to take precedence over making humanity. On the East Cape, things are being put ahead of people via ongoing processes of commodification and dispossession. The slow, grinding process of commodification continues to push residents like Bertha, Pedro, and Angeles aside (see Valiente 2010). Money plays a powerful role in this process.

Keith Hart defines commodification as a process through which people end up working for others via a "progressive abstraction of social labor" (2011:10). Money can help conceal this abstraction and perpetuate exploitation. Money appears to have an unstoppable power that controls our lives as it expands all around the globe, pushing prices, it seems, ever upward. But, as Hart reminds us, Marx's ultimate goal was to show us that the power of money is largely a figment of our imagination, one we mistakenly perceive as the actual source of value itself: "Marx argued that there is some hope of our overcoming this modern form of alienation since, unlike the spirits produced by our religious imagination, we know that human labor is the source of commodities we exchange for money" (2000:262). The meaning of money, Hart (2000:263) argues, is what we make of it.

Money seems to be an almost unstoppable force for many residents of the East Cape. As one activist told me, he expects the whole East Cape will, someday, be "wall to wall" hotels just like Los Cabos. Such fatalism is commonplace; either people fear getting pushed out (like Pedro) or they hold tight for the day when they can sell, make some money, and, they hope, find a new 
place. Many residents do indeed feel alienated and powerless. But there is pushback ( $\mathrm{Li}$ 2014:591; Escobar 2008).

If place can be remade into the abstract, commensurable units of global real estate markets, surely the reverse is also true. The same infrastructural, economic, and communicative networks that work to commodify places can also work toward other ends. Such possibilities were made dramatically apparent during the middle of my fieldwork in Cabo Pulmo in early 2012. The community was caught up in a heated fight against a large-scale development project (Cabo Cortés, mentioned earlier) that had powerful national and international backers, including former Mexican presidents (see Anderson 2014, 2015). During this fight, the community of Cabo Pulmo built strong coalitions with a range of domestic and international allies, activists, citizens, and scholars. The residents made connections via newer forms of communication (such as Twitter and Facebook) but also through older methods-like money, and roads.

In one memorable moment, a group known as the Pacific Voyagers found their way to Pulmo's shores. In brief, the Pacific Voyagers were a collection of scientists, activists, and Native Pacific Islanders who sailed around the world in traditional double-hulled canoes, raising awareness about global environmental and coastal issues. ${ }^{6}$ These visitors represented a coming together of diverse experiences, perspectives, and political struggles. Ironically, although the crew from the Pacific Voyagers had initially planned on sailing directly to Cabo Pulmo itself, weather conditions forced them to seek harbor in Cabo San Lucas. To reach Cabo Pulmo, they rented vehicles and drove out via those dusty, difficult, unpaved roads to share their visionsand values - with local residents. In the end, although money, markets, and roads are often powerful agents of dispossession, this is not automatically so. Perhaps place, like money, is what we make of it. 
Memo is a local fisherman who has lived in Cabo Pulmo his entire life. Once, while talking about money and development in Pulmo, he said, "El dinero manda y el dinero es cabrón" (money talks and money is a bastard). With this, he acknowledged the power and potential duplicity of money. But when I asked him what he would do if someone with a lot of money offered to buy his land, he answered, "No lo vendo. Porque esto es el futuro de mis hijos

aquí en Cabo Pulmo. Dinero no manda todo en el caso de la familia." Roads and global markets are powerful forces, no doubt, but they do not simply and uniformly sweep aside other possibilities, ideals, and values. This is contested territory. People are pushing back. Place, in the end, is where people like Memo — and other residents of the East Cape — hold their ground, and stake their own claims to value, in the face of a rising tide of dispossession.

\section{Notes}

1 Property listings obtained via the Los Cabos MLS at http://www.mlsinbajasur.com/.

2 Numbers are from the Cabo Vinoramas Estates Project, 2016

(http://www.casadelsoleastcape.com/why_now.html).

3 See the CPBR website: http://www.cabopulmoproperties.com/began/.

4 Approximately 4-6 hours from Cabo Pulmo by car.

5 From the Casa del Sol website: http://www.casadelsoleastcape.com/why_now.html.

$6 \mathrm{http}: / /$ pacificvoyagers.org/.

7 Translation: "I will not sell. Money does not determine everything when it comes to family."

\section{References}


Aburto-Oropeza, Octavio, Brad Erisman, Grantly R. Galland, Ismael Mascarenas-Osorio, Enric Sala, and Exequiel Ezcurra

2011 Large Recovery of Fish Biomass in a No-Take Marine Reserve. PLoS One 6(8):1-7. doi:10.1371/journal.pone.0023601

Anderson, Ryan

2014 The Value of a Place: Development Politics on the East Cape of Baja California Sur, Mexico. Ph.D. dissertation, University of Kentucky. http://uknowledge.uky.edu/anthro_etds/15/, accessed August 30, 2016.

2016 Islands within an Almost Island: History, Myth, and Aislamiento in Baja California, Mexico. Shima: The International Journal of Research into Island Cultures 10(1):33-47.

doi:10.21463/shima.10.1.06

Butler, R. W.

1980 The Concept of the Tourist Area Life-Cycle of Evolution: Implications for Management of Resources. Canadian Geographer 24(1):5-12.

Cabral Bowling, María Luisa

1998 La soberanía y el fideicomiso de inmuebles para extranjeros en Baja California Sur. La Paz: UABCS.

Cameron, Catherine M., and John B. Gatewood

2008 Beyond Sun, Sand, and Sea: The Emergent Tourism Programme in the Turks and Caicos Islands. Journal of Heritage Tourism 3(1):55-73.

Cariño, Micheline, Eréndira Valle, Mario Monteforte, Oscar Arizpe C., and Juan Salvador Aceves 
2008 La creación del área natural protegida: Actores, procesos y retos. In Turismo y

sustentabilidad en Cabo Pulmo, BCS. Alba E. Gámez, ed. Pp. 75-98. San Diego, CA: San Diego

State University.

Carter, Pel, and Peg Carter

1967 Trails and Tails of Baja. Lake San Marcos: Southwest Arts.

Castellanos, M. Bianet

2010 A Return to Servitude. Minneapolis: University of Minnesota Press.

Clancy, Michael

2001 Exporting Paradise. New York: Pergamon.

Cohen, Erik

1977 Expatriate Communities. Current Sociology 24:5-90.

Elson, Diane

1979 The Value Theory of Labor. In Value: The Representation of Labour in Capitalism. Diane Elson, ed. Pp. 115-180. London: CSE Books.

Elyachar, Julia

2005 Markets of Dispossession. Durham, NC: Duke University Press.

Escobar, Arturo

2008 Territories of Difference: Place, Movements, Life, Redes. Durham, NC: Duke University

Press.

Gámez, Alba

2008 Turismo y sustentabilidad a la vera de áreas naturales protegidas. In Turismo y sustentabilidad en Cabo Pulmo, BCS. Alba E. Gámez, ed. Pp. 11-30. San Diego, CA: San Diego State University. 
2012 Los Cabos: A Historical Account. In Los Cabos: Prospectives for a Natural and Tourism Paradise. Paul Ganster, Oscar Arizpe C., and Antonina Ivanova, eds. Pp. 203-220. San Diego, CA: San Diego State University Press.

Graeber, David

2001 Toward an Anthropological Theory of Value: The False Coin of Our Own Dreams. New York: Palgrave Macmillan.

2013 It Is Value That Brings Universes into Being. Hau: Journal of Ethnographic Theory 3(2):219-243.

Greenpeace

2010 Cabo Cortés: Destruyendo el paraíso.

http://www.greenpeace.org/mexico/es/Footer/Descargas/reports/Oceanos-y-costas/Cabo-Cortesdestruyendo-el-paraiso1/, accessed June 15, 2016.

Hart, Keith

2000 The Memory Bank: Money in an Unequal World. London: Profile Books.

2011 Building a Human Economy: A Question of Value? Suomen Antropologi: Journal of the Finnish Anthropological Society 36(2):5-17.

Harvey, David

2003 The New Imperialism. Oxford: Oxford University Press.

2006 Spaces of Global Capitalism. London: Verso.

Hiernaux, Daniel Nicolas

1999 Cancún Bliss. In The Tourist City. Denise R. Judd and Susan F. Fainstein, eds. Pp. 124-

142. New Haven, CT: Yale University Press.

Instituto Nacional de Estadistica, Geografía, e Informática (INEGI)

2005 Conteo de Población 2005. Aguascalientes, Mexico. 
2010 Conteo de Población 2010. Aguascalientes, Mexico.

Krutch, Joseph Wood

1986[1961] The Forgotten Peninsula: A Naturalist in Baja California. Tucson: University of Arizona Press.

Lefebvre, Henri

1991 The Production of Space. Oxford: Blackwell.

Li, Tania Murray

2014 What Is Land? Assembling a Resource for Global Investment. Transactions of the Institute of British Geographers 39:589-602. doi:10.1111/tran.12065

Logan, John R., and Harvey L. Molotch

1987 Urban Fortunes: The Political Economy of Place. Berkeley: University of California Press.

López-López, Álvaro, Judith Cukier, and Álvaro Sánchez Crispín

2006 Segregation of Tourist Space in Los Cabos, Mexico. Tourism Geographies 8(4):359-379.

Marx, Karl

1990 Capital: Volume One. London: Penguin Classics.

Mitchell, Don

1996 Introduction: Migratory Workers and the California Landscape, 1913-1942. In Lie of the

Land: Migrant Workers and the California Landscape. Pp. 1-12. Minneapolis: University of

Minnesota Press.

Reyes Bonilla, Hector

1997 Cabo Pulmo Reef: A New Marine Reserve in the Gulf of California. Conservation Biology 11:834-838.

Smith, Neil 
1990 Uneven Development: Nature, Capital, and the Production of Space. Athens, GA: University of Georgia Press.

Topmiller, Michael, Fred Conway, and James Gerber

2011 US Migration to Mexico: Numbers, Issues, and Scenarios. Mexican Studies/Estudios

Mexicanos 27(1):45-71.

Torres, Rebecca Maria, and Janet D. Momsen

2005 Gringolandia: The Construction of a New Tourist Space in Mexico. Annals of the Association of American Geographers 95(2):314-355.

Valiente, Carmina

2010 Baja All-Exclusive. Carmina Valiente, dir. https://vimeo.com/25102507, accessed June 29, 2016.

Weiant, Pamela A.

2005 A Political Ecology of Marine Protected Areas (MPAs): Case Study of Cabo Pulmo National Park, Sea of Cortez, Mexico. Ph.D. dissertation, University of California, Santa Barbara.

Williams, Brett

2001 A River Runs through Us. American Anthropologist, 103:409-431.

doi:10.1525/aa.2001.103.2.409

Wilson, Tamar Diana

2008 Economic and Social Impacts of Tourism in Mexico. Latin American Perspectives 35(3):37-52. 